\title{
The Use of Gabapentin for the Treatment of Alcohol and Tobacco Use Disorders: A Review
}

This article was published in the following Dove Press journal:

Open Access Journal of Clinical Trials

\author{
Gabriel C Quintero Garzola \\ Florida State University- Republic of \\ Panama, Panama City, Panama
}

Background: Alcohol and tobacco use disorders are pervasive health problems without adequate treatment. Gabapentin has been used for different psychiatric disorders, including addiction.

Methods: In this article, the use of gabapentin for the treatment of alcohol and tobacco use disorders is reviewed. Accordingly, a database search of PubMed was performed (January 1, 1983-August 31, 2017), using the search terms "gabapentin" AND "alcohol" OR "tobacco". Animal and human studies written in English were included. A total of 426 records were identified, and 40 articles met eligibility criteria and were included in this review. The main reasons for exclusion were gabapentin was not the intervention of interest or the study population did not have alcohol/tobacco abuse issues. Additionally, 28 references were included in the Introduction, for a total of 68 references. The success of gabapentin for treating alcohol/tobacco use problems was determined by calculating the success rate across studies: the total number of investigations with favorable results was divided by the total numbers of investigations for each specific disorder (eg, alcohol or tobacco dependence, or other).

Results and Discussion: The available evidence on gabapentin for alcohol use disorder suggests that this treatment successfully alleviates problems related to alcohol abuse, including withdrawal symptoms, dependence, and cravings. However, more research is needed to determine the effectiveness of gabapentin for preventing relapse. Further, more data are required before a conclusion regarding gabapentin's effectiveness for treating tobacco dependence.

Keywords: gabapentin, alcohol, tobacco, addiction, review

\section{Introduction}

\section{Advantages of Gabapentin for Treating Addiction}

Gabapentin is an anticonvulsant medication that has been recognized for its potential in alleviating substance use disorders-related symptoms. ${ }^{1,2}$ Gabapentin displays a relatively low addiction potential, enables a comfortable and secure detoxification process, protects from withdrawal-related seizures, and may help in treating comorbid psychiatric disorders. ${ }^{1}$ It has been previously reported that gabapentin may help in the treatment of cocaine dependence, and aid in alcohol and benzodiazepine detoxification. ${ }^{1}$ Further, gabapentin is comparatively safe compared to other medications used for substance use disorders. ${ }^{2}$ Based on this literature suggesting gabapentin may be beneficial for treating substance use problems, the present review aims to evaluate gabapentin's potential for treating problems related to tobacco and alcohol use, the two most frequently abused substances.
Correspondence: Gabriel C Quintero Garzola

Florida State University - Republic of

Panama, City of Knowledge, Clayton No.

227, Panama City, Panama

Tel +507 317-0367

Fax +507 317-0366

Email gquintero@fsu.edu 


\section{General Features of Gabapentin}

Gabapentin, also known by its brand names Fantarex, Horizon, Neurontin, and Gralise, is a white, crystalline solid with the chemical formula $\mathrm{C}_{9} \mathrm{H}_{17} \quad \mathrm{NO}_{2}$ and a molecular weight of $171.24 \mathrm{~g} / \mathrm{mol}^{3}{ }^{3}$ It is packaged in $100-400 \mathrm{mg}$ capsules or $300-800 \mathrm{mg}$ tablets. ${ }^{4}$

Gabapentin reaches maximum plasma concentrations within 3-4 hours and has an elimination half life of around 6 hours, excreted through the renal route. ${ }^{5}$ When taken orally, gabapentin has a low and saturable absorption (a nonlinear process, zero-order). Gabapentin does not bind to plasma proteins, nor is it inhibited or metabolized by hepatic enzymes. ${ }^{5}$ Finally, its plasma concentration does not augment proportionally in function of doses augmentation. ${ }^{5}$

\section{Mechanisms of Action of Gabapentin}

Gabapentin displays its anticonvulsant properties by hindering the functioning of presynaptic voltage-gated sodium and calcium channels and, in turn, reducing exocytosis and neurotransmitter release in order to reduce neural transmission. ${ }^{6-10}$ Gabapentin also hinders the formation of new synapses by attaching to the $\alpha 2 \delta 1$ subunit of calcium channels, and therefore blocks the interaction between thrombospondins (released by glia cells) and the $\alpha 2 \delta 1$ subunit, which consequently inhibits the promotion of excitatory synapses. ${ }^{11,12}$ Gabapentin has been marketed as a medication with a low side effect and toxicity profile. ${ }^{1,2}$ However, recent investigation in Europe has challenged this, finding addiction and withdrawal symptoms related to gabapentin, even in patients without a history of substance use disorder. ${ }^{13}$

\section{Clinical Use of Gabapentin}

In the past few decades, gabapentin has been tested in preclinical and clinical studies. ${ }^{14-17}$ Originally, gabapentin was investigated for the treatment of epilepsy, ${ }^{18,19}$ but has been subsequently explored for the treatment of other disorders such as psychiatric disorders, behavioral dyscontrol, ${ }^{20,21}$ amyotrophic lateral sclerosis, ${ }^{22}$ neuropathic pain, ${ }^{23,24}$ neuralgia, ${ }^{27}$ and restless legs syndrome. $^{28,29}$

An early study of gabapentin in rodents reported broad spectrum anxiolytic effects. ${ }^{26}$ Further, a study of individuals with bipolar disorder $(n=75)$ reported that gabapentin relieved cyclicity, and improved mood, appetite, memory, attention, energy, sleep, and libido. ${ }^{25}$

\section{Purpose of the Present Scientific Work}

The present article aims to review the use of gabapentin for treating problems related to alcohol and tobacco use disorders. Previous reviews have described the use of gabapentin for treating alcohol use disorder, ${ }^{30-39}$ but, few have described the use of gabapentin for treating tobacco use disorders. ${ }^{32,40,41}$ To date, no review has focused exclusively on the use of gabapentin for the treatment of tobacco use disorder.

\section{Gabapentin Use in Treating Alcohol-Related Problems}

The majority of studies that have explored the use of gabapentin for treating alcohol use disorders have included withdrawal symptoms, ${ }^{42-53}$ dependence and craving, ${ }^{54-58}$ relapse, ${ }^{59}$ and other subjective and physiological effects of alcohol. ${ }^{60}$ Other, pre-clinical studies have examined cellular mechanisms and behavioral interactions of gabapentin with alcoholism. ${ }^{61,62}$

\section{Gabapentin Use in Treating Alcohol-Withdrawal Symptoms}

The publications that evaluated the effects of gabapentin on alcohol-withdrawal symptoms are summarized in the next three paragraphs. ${ }^{42-53}$ Firstly, a small clinical study (n $=4$ ) of in-patients with moderate alcohol-withdrawal syndromes evaluated the addition of gabapentin ( $400 \mathrm{mg}$ qid) to clomethiazole and found that this combination reduced the amount of clomethiazole needed. The authors suggested this combination be explored for alcoholwithdrawal treatment in larger-scale studies. ${ }^{42}$ Another small clinical investigation $(\mathrm{n}=3)$ found that gabapentin (400 mg tid for $3 \mathrm{~d}, 400 \mathrm{mg}$ bid for $1 \mathrm{~d}$, and $400 \mathrm{mg}$ for 1 d) was effective in alleviating alcohol-withdrawal symptoms without side effects; further larger and systematic studies are recommended. ${ }^{43}$ Another study $(\mathrm{n}=30)$ reported that gabapentin $(3 \times 300 \mathrm{mg} / \mathrm{d}$, for up $30 \mathrm{~d})$ was useful for controlling tonic-clonic seizures in alcoholwithdrawal syndrome, with a good safety profile. ${ }^{44}$ Moreover, a randomized and open-label study $(n=27)$ found that gabapentin was as effective as phenobarbital for treating alcohol-withdrawal syndrome. ${ }^{45}$ Considering gabapentin's favorable pharmacokinetic profile, further investigations into its effectiveness in treated alcoholwithdrawal symptoms are recommended. ${ }^{45}$

Moreover, a clinical study $(\mathrm{n}=68$, completed followups) reported that gabapentin surpassed lorazepam 
regarding sleep problems associated with alcoholwithdrawal syndrome (insomnia and day time sleepiness). ${ }^{46}$ On the other hand, another human randomized and double-blind investigation $(\mathrm{n}=100)$ in an outpatient sample ${ }^{47}$ found that gabapentin $(900 \mathrm{mg}$ tapering to $600 \mathrm{mg}$, or 1200 tapering to $800 \mathrm{mg}$ ) surmounted lorazepam (6 mg tapering to $4 \mathrm{mg}$ ) after $4 \mathrm{~d}$ of treatment, regarding alleviation of alcohol-withdrawal symptoms. Gabapentin showed a better profile regarding the treatments of craving, anxiety, sedation, tolerance, number of symptoms, and alcohol intake, especially at higher doses $(1200 \mathrm{mg}){ }^{47}$ Also, a randomized study $(\mathrm{n}=150)$ in alcohol-dependent participants found that the combination of gabapentin (up to $1200 \mathrm{mg} / \mathrm{d}$ ) and naltrexone $(50 \mathrm{mg} / \mathrm{d}$ ) surmounted naltrexone $(50 \mathrm{mg} / \mathrm{d})$ or placebo conditions for treating alcohol dependence (eg, reduction of drinking episodes, and less poor sleep). ${ }^{48}$ Moreover, another randomized-double blind investigation in a sample of USA ambulatory veterans $(n=26)$ reported that gabapentin (1200 mg orally for $3 \mathrm{~d}$, followed by $900 \mathrm{mg}, 600 \mathrm{mg}$, and $300 \mathrm{mg}$ for $1 \mathrm{~d}$ each) outperformed chlordiazepoxide (1200 mg orally for $3 \mathrm{~d}$, followed by $900 \mathrm{mg}, 600 \mathrm{mg}$, and $300 \mathrm{mg}$ for $1 \mathrm{~d}$ each) for treating alcohol-withdrawal symptoms (lower sedation, reduced craving) ${ }^{49}$ these authors recommended subsequent studies with larger samples. $^{49}$

On the other hand, a double-blind study ( $\mathrm{n}=46$, out of 59 randomized subjects) informed that gabapentin speeded the improvement of acute withdrawal syndrome within 48 $\mathrm{h}$; this effect was specially marked in subjects with comorbid depression. ${ }^{51}$ Also, other double-blind and randomized investigation in alcohol-dependent subjects $(n=61)$ reported that gabapentin treatment (400 mg qid) during 7 $\mathrm{d}$ was not better than placebo, in reducing the initial consumption of clomethiazole, or alleviating alcohol acute withdrawal symptoms. ${ }^{52}$ Furthermore, a clinical investigation in a sample of inpatients $(\mathrm{n}=37)$ with severe alcohol-withdrawal symptoms informed that gabapentin (800 $\mathrm{mg}$ po, loaded up to $3200 \mathrm{mg}$ in the first $24 \mathrm{~h}$ ) alleviated only mild and simpler acute alcoholwithdrawal symptoms. ${ }^{53}$

Integrating the different investigations that have used gabapentin for treating alcohol-withdrawal symptoms, it can be stated the next: a) It is evident that the majority showed satisfactory results. b) Within this majority, some have used gabapentin alone, ${ }^{43-47,49,51,53}$ and few others have combined it with clomethiazole, ${ }^{42}$ or naltrexone. ${ }^{48}$ c) Gabapentin has been regarded as a drug with a safe profile. ${ }^{43,44}$ d) The doses in the successful studies have been in a range of 300 to $1200 \mathrm{mg} / \mathrm{d}$ of gabapentin; ${ }^{43,44,47,49,53}$ one of these studies recommended the $1200 \mathrm{mg} / \mathrm{d}$ dose. ${ }^{47}$ e) The number of days for gabapentin treatment was from 1 to $30 \mathrm{~d}: 1 \mathrm{~d},{ }^{53} 4 \mathrm{~d},{ }^{47} 5 \mathrm{~d},{ }^{43} 6$ $\mathrm{d},{ }^{49}$ and up to $30 \mathrm{~d} .{ }^{44} \mathrm{f}$ ) The regimen of gabapentin's doses was variable: escalated, ${ }^{53}$ tapered, ${ }^{43,47,49}$ or fix doses. ${ }^{44} \mathrm{~g}$ ) Other few successful studies combined gabapentin with other drugs, like clomethiazole and naltrexone, and the gabapentin doses employed were $400 \mathrm{mg}$ qid, and up to $1200 \mathrm{mg} / \mathrm{d}$, respectively; ${ }^{42,48}$ hence, doses were in the range of 1200 to $1600 \mathrm{mg} / \mathrm{d}$. h) Successful studies with small to moderate sample sizes ( $\mathrm{n}=3,4$, and 26) recommended further studies with larger samples. ${ }^{42,43,49}$

\section{Gabapentin Use in Alleviating Alcohol Dependence and Craving}

Regarding the scientific works that explored the use of gabapentin for treating alcohol dependence and craving, these are summarized in the next two paragraphs. ${ }^{54-58}$

A randomized, double-blind, placebo-controlled investigation in male alcohol dependent outpatients $(n=60)$ reported that gabapentin treatment $(600 \mathrm{mg} / \mathrm{d}$, during $28 \mathrm{~d})$ reduced alcohol consumption and craving (compared to placebo tablets). ${ }^{54}$ Furthermore, gabapentin had few side effects and is safer. ${ }^{54}$ On the other hand, another doubleblind study in a bar-laboratory setting, tested nontreatment-seeking alcoholics $(\mathrm{n}=35) .{ }^{55} \mathrm{It}$ was found that gabapentin (up to $1200 \mathrm{mg}$ ) administered during $8 \mathrm{~d}$ had no effect on alcohol drinking or its craving; also, alcohol was tolerated (like placebo) over $5 \mathrm{~d}$ of natural drinking. This suggested that gabapentin is safe during alcohol consumption (not disruptive interactions). ${ }^{55}$

Moreover, a random design study $(\mathrm{n}=21)$ with alcoholic dependent subjects (men and women) with insomnia found that gabapentin significantly delayed the onset of heavy drinking (it lasted beyond the end of the treatment).$^{56}$ Because gabapentin was taken only at night time during the study, it tentatively exerted a nightly effect that prevents relapse to heavy drinking by a physiological process not tested in the investigation. ${ }^{56}$ On the other hand, other randomized research in alcohol-dependent individuals ( $\mathrm{n}=60$, with high or low alcohol withdrawal) evaluated these by means of flumazenil $(2 \mathrm{mg}$ of incremental bolus for $20 \mathrm{~min}$ for 2 consecutive d) or gabapentin (up to $1200 \mathrm{mg}$ nightly for $39 \mathrm{~d}$ ). ${ }^{57}$ This study concluded that there is a differential response to flumazenil or 
gabapentin treatment, depending of the pre-treatment status of the alcohol withdrawal. ${ }^{57}$ Finally, other randomized double-blind investigation in 150 alcohol-dependent participants (men and women) belonging to an outpatient clinical station found that gabapentin (0 $\mathrm{mg}$ [placebo], $900 \mathrm{mg}$, or $1800 \mathrm{mg} / \mathrm{d}$ ) combined with guidedcounseling, significantly ameliorated the abstinence and drinking problems, without relevant adverse effects. Also, analogous dose-dependent effects were observed in the alleviation of mood, sleep and craving problems. ${ }^{58}$

Unifying the studies previously described about dependence and craving, the next can be affirmed: a) All the studies have been randomized, ${ }^{54,56-58}$ and/or double blind. ${ }^{54,55,58}$ b) The samples sizes have ranged between 21 and 150 subjects: $21,{ }^{56} 35,{ }^{55} 60,{ }^{54}$ and $150,{ }^{58}$ and few included both genders. ${ }^{56,58} \mathrm{c}$ ) The studies have been successful, and employed gabapentin doses in a range from 600 to $\left.1800 \mathrm{mg} / \mathrm{d}^{54,55,57,58} \mathrm{~d}\right)$ The range of days for gabapentin treatment was from 8 to $39 \mathrm{~d}$ : $8 \mathrm{~d},{ }^{55} 28 \mathrm{~d},{ }^{54}$ and $39 \mathrm{~d}^{57}$ e) Gabapentin was regarded as safe and with scarce side effects. ${ }^{54,55,58}$ f) The benefits of gabapentin found were: effective for reducing alcohol consumption and/or craving, ${ }^{54,58}$ it does not augment the adverse effects of alcohol (bar lab), ${ }^{55}$ it delayed the onset of heavy drinking. ${ }^{56}$ Furthermore, the benefit of gabapentin for treating alcohol dependence was influenced by the pretreatment withdrawal status (low or high alcohol withdrawal). ${ }^{57}$

\section{Gabapentin Use in Treating Alcohol Relapse and Rodent Research}

Finally, the investigations that analyzed the effectiveness of gabapentin for treating human alcohol relapse, ${ }^{59}$ the subjective and physiological effects of alcohol, ${ }^{60}$ and related rodent work $^{61}$ are condensed in the next two sections:

First, an investigation of alcohol-dependent individuals $(n=33)$ by means of a cue-reactivity design found that gabapentin treatment $(1200 \mathrm{mg})$ during 1 week might be effective for treating the extended abstinence phase (reduction of subjective and affectively evoked cravings); ${ }^{59}$ also, gabapentin improved sleep quality with minimal side effects. These authors recommended to follow further randomized clinical trials. ${ }^{59} \mathrm{On}$ the other hand, a double-blind research in volunteers without alcohol dependence $(n=17)$ found that acute gabapentin treatment (doses: 0, 1000, or $2000 \mathrm{mg}$ ) influenced the effects of heavy drinking alcohol $(0.75 \mathrm{~g} /$ $\mathrm{kg}){ }^{60}$ Specifically, this research reported that gabapentin disrupted the capacity to balance, and augmented alcohol-induced tachycardia (dose-dependently). Furthermore, the combination of acute gabapentin treatment and alcohol was well tolerated, and it did not alter the effects of alcohol (craving; and subjective/performance effects). ${ }^{60}$

On the other hand, a rat investigation found that systemic gabapentin reduced ethanol intake only in dependent group of rats; also, gabapentin reversed the anxiogeniclike effect of ethanol abstinence (based on an acute dependence model). ${ }^{61}$ Moreover, the infusion of gabapentin in the central nucleus of the amygdala blocked dependenceinduced elevation in the operant ethanol responding. ${ }^{61}$ This investigation suggested that gabapentin is a potential medication for treating alcoholism. ${ }^{61}$

Integrating the researches previously cited above alcohol relapse, subjective and physiological effects of alcohol, and the rodent study, it can be affirmed the next: a) Gabapentin can influence the effects of alcohol (capacity to balance, tachycardia) ${ }^{60}$ b) Regarding the influence of gabapentin on the subjective effects and alcohol craving, studies showed opposed tendencies: one study stated that gabapentin does not alter alcohol craving, neither its subjective and performance effects. ${ }^{60}$ However, the other study reported that gabapentin can reduce subjective alcohol and affectively evoked cravings. ${ }^{59}$ c) The rodent study supports the use of gabapentin for treating alcohol dependence, and the anxiety concomitant to abstinence. ${ }^{61}$

\section{Gabapentin Use in Treating Tobacco-Related Problems}

The researches about the use of gabapentin for treating tobacco-related problems have investigated the effectiveness of gabapentin for treating diverse tobacco-related problems like smoking abstinence, dependence, and withdrawal symptoms. ${ }^{63-65}$

Specifically, a single-arm and open-label study by Sood group (2007) on adult smokers $(\mathrm{n}=50)$ administered gabapentin $(1800 \mathrm{mg} / \mathrm{d})$ during 8 weeks combined with brief behavioral intervention. ${ }^{64}$ It found that gabapentin eased smoking abstinence. Also, subjects that keep smoking (and followed assessments) decreased their daily number of cigarettes, compared to baseline. Furthermore, the side effects were slighter and well tolerated. ${ }^{64}$ The investigators recommended a random study with a larger 
sample and contrasting different gabapentin doses and placebo group. ${ }^{64}$

On the other hand, another study by Sood group (2010) with a sample of 80 participants used gabapentin (1800 to $2700 \mathrm{mg} / \mathrm{d}$ ) or placebo. ${ }^{63}$ The treatment followed the next regimen: the first 2 weeks were dose titration, then the target dose maintained for 9 weeks, and later tapered over 1 week. It was not found differences between gabapentin and placebo regarding smoking reduction. This study concluded that 1800 to $2700 \mathrm{mg} / \mathrm{d}$ dose of gabapentin was not useful for treating tobacco dependence. As reference, a limitation of this study was a marked dropout rate (more than 50\%). ${ }^{63}$

Finally, an open-label randomized study of 6 weeks, compared gabapentin $(n=17)$ and bupropion $(n=19)$ for smoking reduction, and alleviation of withdrawal syndrome severity. ${ }^{65}$ Gabapentin was less efficacious than bupropion for smoking cessation. However, gabapentin has lower dropouts because of adverse effects. Also, the withdrawal syndrome was more severe with gabapentin (compared to bupropion). ${ }^{65}$ It seems that bupropion surpassed gabapentin as treatment for smoking cessation. This investigation advised to perform more studies for exploring potential gabapentin benefits for smoking cessation. ${ }^{65}$

Taking these studies together, it seems necessary: a) Follow further studies with random samples (rather than open label), covering a broader range of gabapentin doses (900 to $2700 \mathrm{mg} / \mathrm{d}$ ), and include placebo group. b) Adding brief behavioral intervention to gabapentin might allow better results, but this should be tested with further studies. c) The studies checked are inconsistent, showing either gabapentin eases smoking abstinence, and allows lower side effects, but also opposed tendencies. The same is found regarding withdrawal symptoms alleviation.

\section{Methods}

\section{Inclusion and Exclusion Criteria}

Human (clinical) and non-human (pre-clinical/basic) studies with an experimental or quasi-experimental design that examined the effect of gabapentin, given alone or in combination with other drugs, for the treatment of alcohol or tobacco use disorders or related issues were included. Articles were required to be mainly experimental, quantitative and/or clinical (but revisions were included for purpose of the introduction section), detail the number of participants, and be written in English. Abstracts without full-text articles, conference reports, and non-scientific publications were excluded.

\section{Search Strategy}

A database search of PubMed from January 1, 1983, to August 31, 2017, was completed using the search terms: "gabapentin" AND "alcohol" OR "tobacco". PRISMA reporting guidelines were followed. Originally, 426 were acquired from the Pubmed database output. After revising the titles and resumes, 386 references were ruled out, resulting in 40 references for subsequent analysis. The complete (full) forms of the 40 references were obtained on the web, or solicited to the authors, and evaluated for the preparation of the revision. After the references (full versions) were analyzed, 40 were maintained for the elaboration of the review. Furthermore, 28 complementary references were obtained by means of reference exploration or web search and were added for describing gabapentin (background) in the Introduction part. More details are described in Figure 1, following PRISMA guidelines.

\section{Calculating Gabapentin Success in Alleviating Alcohol or Tobacco Use Problems}

To determine the success of gabapentin, percentages were determined using the formula presented in Figure 2. A study was classified as successful if it fulfilled any of the following requirements:

1. If gabapentin alone was superior to a control condition (typically placebo).

2. If gabapentin combined with another treatment was superior to a control condition.

3. If gabapentin alone was superior to another treatment and to a control group.

4. If gabapentin combined with another treatment was superior to another treatment and to a control group.

5. If participants improved from baseline after receiving gabapentin alone or in combination with another treatment, without the use of a control group (ie, open-label study)

\section{Results}

\section{Clinical Studies on the Use of Gabapentin in Treating Alcohol-Withdrawal \\ Symptoms}

Gabapentin was used in a total of 12 studies between 1996 and 2013, 11 of which published a successful result 


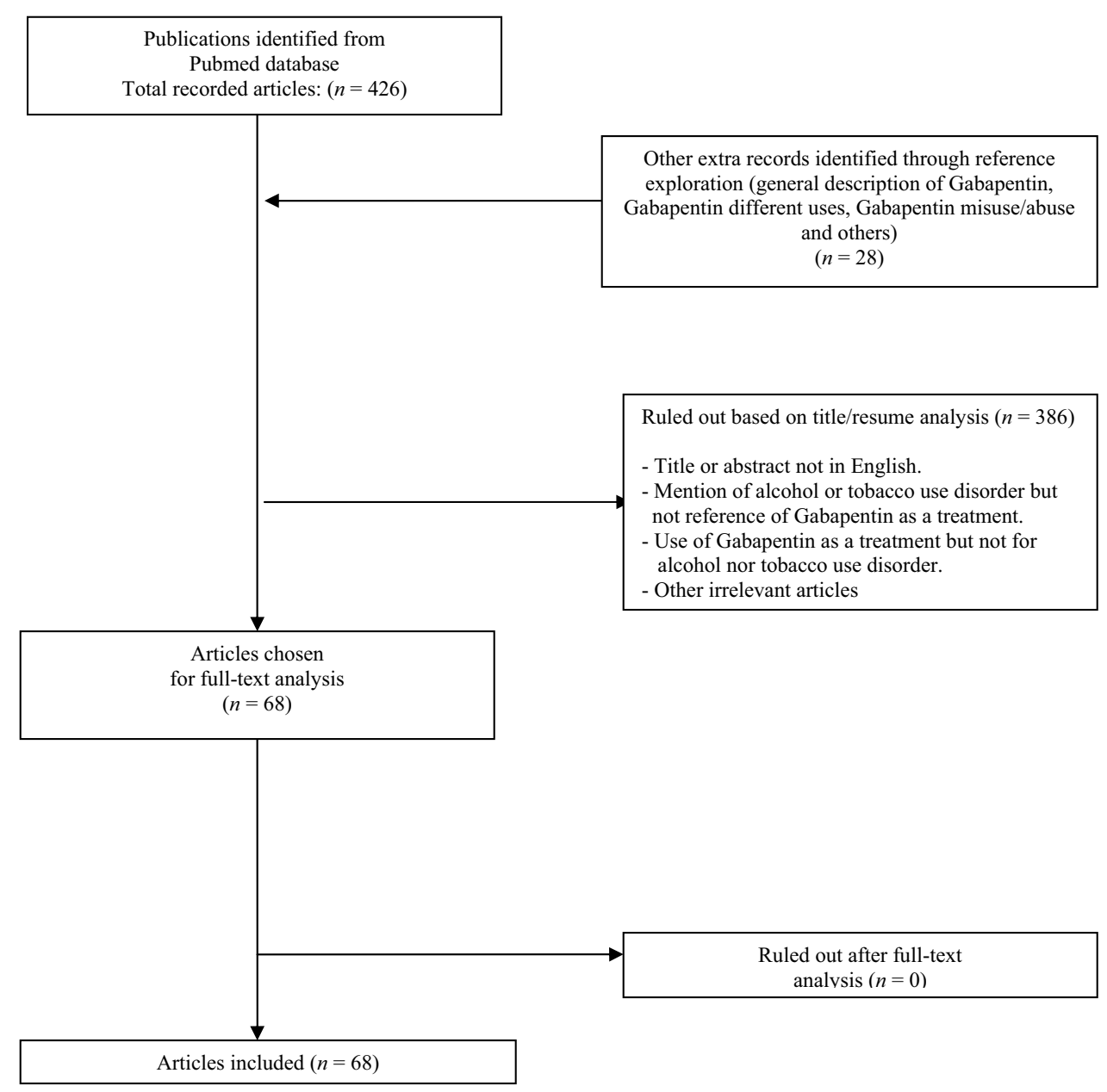

Figure I The diagram shows the strategy used for manuscript selection, following PRISMA guidelines, beginning from initial PubMed database screening, up to the final manuscripts included in the work.

(\# of favorable investigations)

(\# of favorable investigations + \# of unfavorable investigations)
$X 100=\%$ of successful

investigations

Figure 2 Formula used for calculating the percentage of favorable outcome. To estimate the percentage of successful investigations, a formula was used, which consists of dividing the number of favorable investigations among the total number of investigations carried out (favorable and unfavorable). Later the result of this division was multiplied by 100 .

(91.7\%). The sample size for these studies ranged from 3 to 150 at enrollment, and 3 to 146 at end-of-study. While this is a broad range, calculating this percentage for studies with larger sample sizes only ( $\mathrm{n}$ enrolled $=26-150, \mathrm{n}$ final =17-146) yielded a similar result: success in 8 out of 9 $(88.9 \%)$ of studies.

Gabapentin was used alone (without any other intervention) in five studies, combined with another drug in three, and contrasted against other drugs in four. All the studies that assessed gabapentin only reported successful results. $^{43,44,51,53,67}$ Moreover, gabapentin was useful for reducing tonic-clonic seizures, improving mood, and reducing both less severe and complicated acute withdrawal symptoms. The dosage applied during these studies ranged from 400 to $3200 \mathrm{mg} / \mathrm{d}$, and the treatment length ranged from two to 30 days.

Two out of the three works that employed gabapentin combined with other drugs reported successful results. ${ }^{42,48,52}$ The combination of gabapentin with clomethiazole showed equivocal results; in one study, ${ }^{42}$ gabapentin reduced the amount of clomethiazole needed, and in another it had no effect clomethiazole consumption. ${ }^{52}$ Other research showed that gabapentin combined with naltrexone surpassed the effects of naltrexone alone. ${ }^{48}$ 
When considering only studies of larger sample sizes ( $\mathrm{n}$ enrolled $=26-150, \mathrm{n}$ final $=17-146$ ), gabapentin was used alone (without any other drug) in three studies, combined with another drug in two, and contrasted again other drugs in four. All the investigations of gabapentin alone for treating alcohol-withdrawal symptoms reported successful results. Furthermore, gabapentin was useful for reducing tonic-clonic seizures, improving mood, and controlling less severe and complicated acute withdrawal symptoms. The dosages applied in these investigations ranged from 400 to $3200 \mathrm{mg} / \mathrm{d}$, and treatment length ranged from two to 30 days. Only one (50\%) of the studies combining gabapentin with another treatment reported successful results. ${ }^{48,52}$ When gabapentin was combined with clomethiazole, there was no effect on amount of clomethizole needed. ${ }^{52}$ However, in another investigation that combined gabapentin with naltrexone, the combination surpassed the effects of naltrexone alone. ${ }^{48}$

In the pair of studies that combined gabapentin and clomethiazole ( $\mathrm{n}$ enrolled $=4-61, \mathrm{n}$ final $=4$ to 54$),{ }^{42,52}$ the dosage administered ranged from 0 to $1600 \mathrm{mg} / \mathrm{d}$ for gabapentin and 0 to $2208 \mathrm{mg} / \mathrm{d}$ for clomethiazole; the duration of treatment ranged from 4 to 7 days. The two studies that combined gabapentin and clomethiazole showed opposing results: the one with a larger sample ( $\mathrm{n}$ enrolled $=61$ ) reported a negative result and the other with a small sample size $(\mathrm{n}=4$, initial sample size) reported a favorable result. This contrast might be explained by the differences in sample sizes (4 vs 61), the days of treatment ( $4 \mathrm{~d}$ in the small sample vs $7 \mathrm{~d}$ in the large sample), and the severity of the alcohol problems between groups; the study with smaller sample enrolled participants with moderate alcohol abuse severity, while the larger study enrolled individuals with alcohol dependence. Range of doses of gabapentin and clomethiazole were roughly the same between both studies (more details in Table 1).

Only one investigation $(\mathrm{n}$ enrolled $=150)$ combined gabapentin and naltrexone: ${ }^{48}$ gabapentin dosage ranged from 300 to $1200 \mathrm{mg} / \mathrm{d}$ and the naltrexone from 25 to $50 \mathrm{mg} / \mathrm{d}$. Treatment lasted 112 days. The overall initial sample was a total of 150 subjects.

All the experimental works that contrasted gabapentin to other drugs for treating alcohol-withdrawal symptoms reported successful results. Sample size ranged from 26 to 75 at enrollment ( $\mathrm{n}=17$ to 68 , final sample). ${ }^{45-47,49}$ Specifically, the studies reported that gabapentin was as useful as phenobarbital, surpassed lorazepam (used for sleep problems), and surpassed chlordiazepoxide (sedation and cravings) for improving withdrawal symptoms.

In the pair of studies that compared gabapentin and lorazepam, ${ }^{46,47}$ the range of dosages administered was 400-1200 mg/d for gabapentin, and 4-6 mg/d of lorazepam; the treatment lasted a total of 4 days. The initial sample ranged from 56 to 75 subjects. In the investigation that compared gabapentin and phenobarbital, ${ }^{45}$ the range of dosages administered was $1200-2400 \mathrm{mg} / \mathrm{d}$ for gabapentin, and $60-180 \mathrm{mg} / \mathrm{d}$ for phenobarbital; the treatment lasted 4 days, the initial sample size was 23 subjects. Finally, in the study that compared gabapentin and chlordiazepoxide, ${ }^{49}$ dosage ranged from 300 to $1200 \mathrm{mg} /$ $\mathrm{d}$ of gabapentin, and $25-100 \mathrm{mg} / \mathrm{d}$ of chlordiazepoxide. Treatment lasted 6 days and 26 subjects were enrolled.

Table 1 summarizes clinical studies assessing the use gabapentin for treating alcohol withdrawal.

\section{Clinical Studies on the Use of Gabapentin in Treating Alcohol Dependence and Craving}

Gabapentin was employed in a total of five works between 2007 and 2014, with sample sizes ranging from 21 to 150 at enrollment ( $\mathrm{n}=20-85$ at end-of-study). Four out of five trials $(80 \%)$ published a successful result. Gabapentin was used uncombined (without any other drug) in four studies, and combined with another drug in one study.

Three out of the four studies (75\%) that used gabapentin alone for treating alcohol dependence and craving showed successful results. ${ }^{54,56,58}$ Specifically, these studies reported that gabapentin was useful for reducing dependence and cravings, and delayed heavy drinking. Zero to $1500 \mathrm{mg} / \mathrm{d}$ gabapentin was given across these studies, and treatment lasted 28 to 84 days. Sample size ranged from 21 to 150 subjects. A possible explanation for the lack of success in the study by Myrick and colleagues (2007) is the shorter duration of treatment ( 8 days) compared to the successful studies (28 to 84 days) ${ }^{55}$ the dosage given (300-1200 mg/d) did not differ from that in the successful studies $(0-1500 \mathrm{mg} / \mathrm{d})$. A treatment length of 8 days might not be sufficient considering the participants had a severe alcohol problem (alcohol dependence) rather than a moderate one.

The combination of gabapentin and flumazenil was successful only in participants that had more severe withdrawal symptoms before the treatment. ${ }^{57}$ In this study ( $\mathrm{n}=$ 60), 0-1200 mg/d gabapentin and $2 \mathrm{mg} / \mathrm{d}$ flumazenil were 


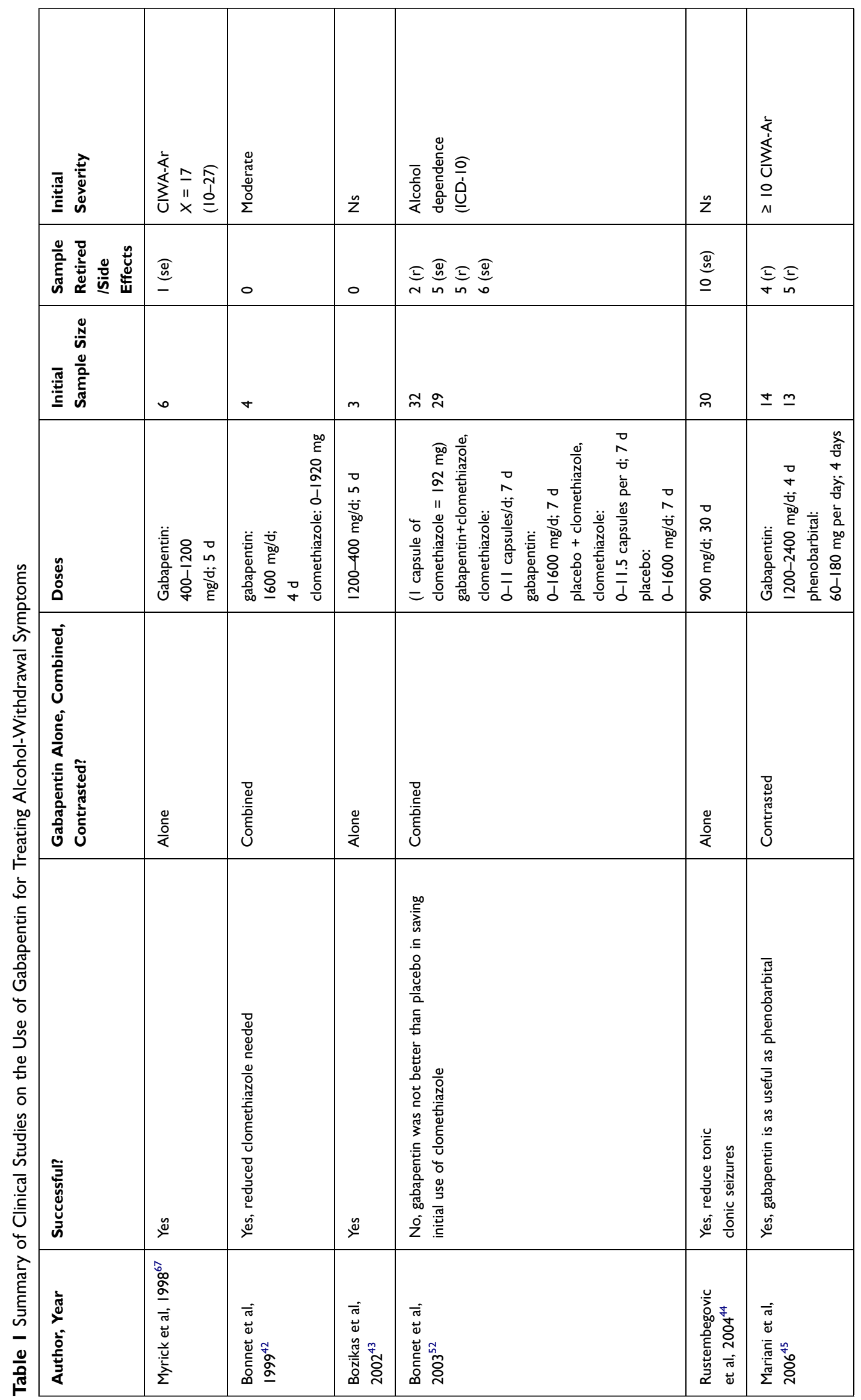




\begin{tabular}{|c|c|c|c|c|c|}
\hline & 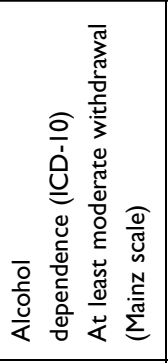 & 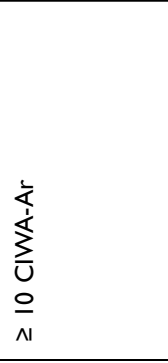 & 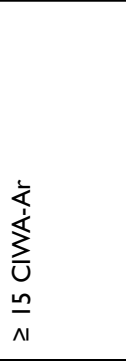 & $\underline{z}$ & 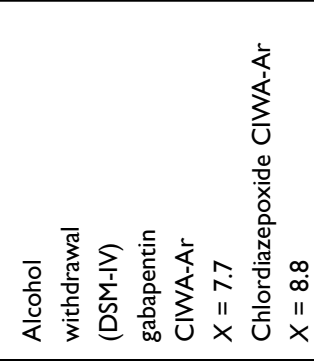 \\
\hline$\stackrel{\Xi}{\Sigma}$ & 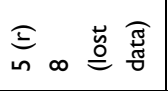 & 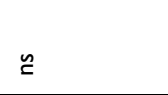 & $\underset{\sim}{\stackrel{\widetilde{d}}{N}}$ & $\Xi$ & $\begin{array}{l}\text { હ } \cong \\
0 \mathrm{~m}\end{array}$ \\
\hline n & $\pm \widetilde{N}$ & $\stackrel{\infty}{\sim} \stackrel{\infty}{\sim}$ & $\hat{m}$ & in in in & $=\sigma$ \\
\hline 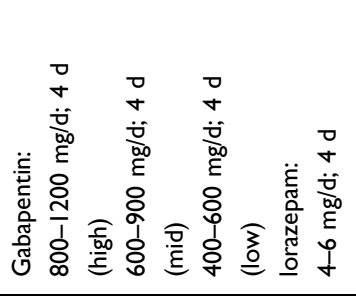 & 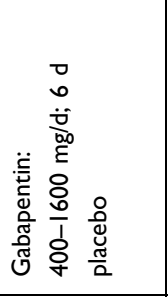 & 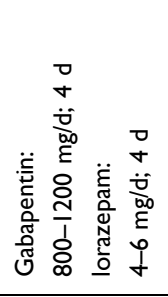 & 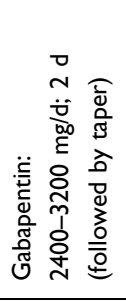 & 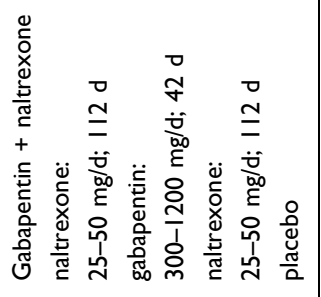 & 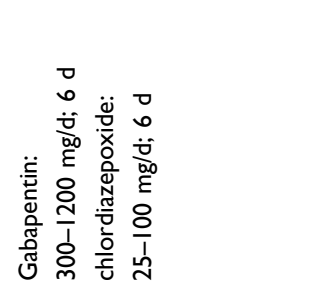 \\
\hline 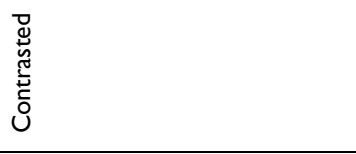 & $\frac{\stackrel{0}{0}}{\frac{0}{4}}$ & 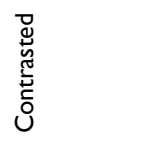 & $\frac{\stackrel{0}{0}}{\stackrel{0}{\frac{0}{4}}}$ & 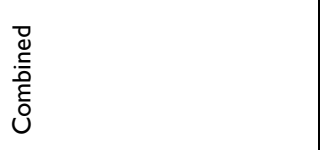 & 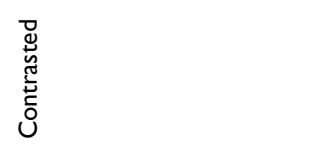 \\
\hline 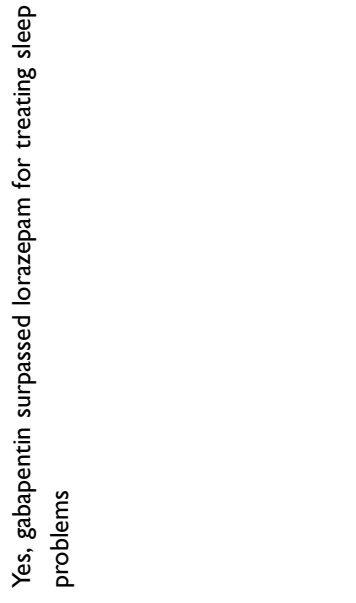 & 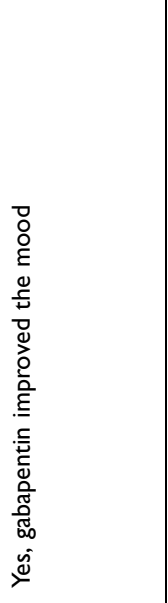 & 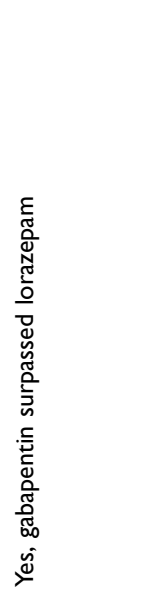 & 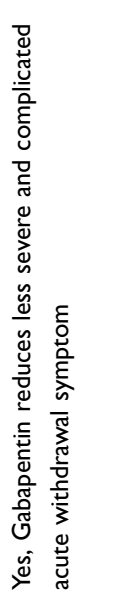 & 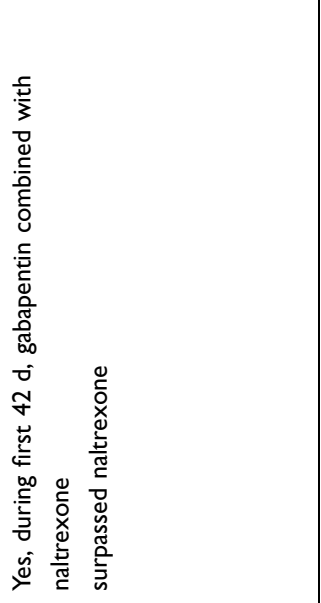 & 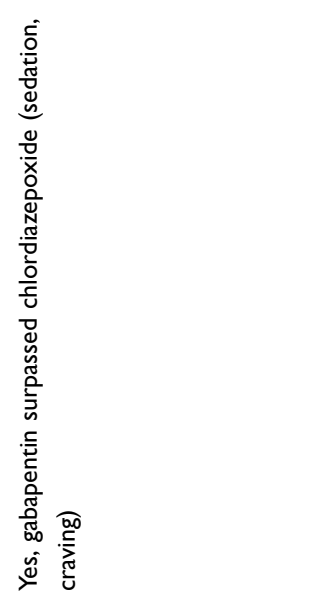 \\
\hline 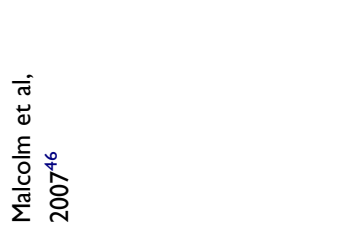 & 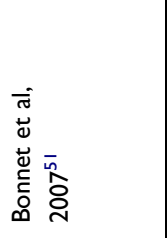 & 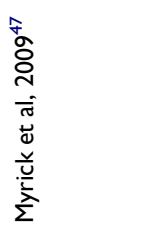 & 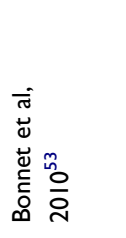 & 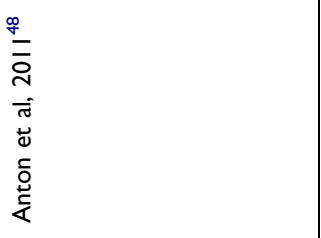 & 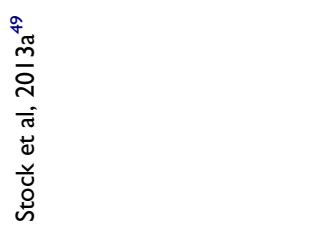 \\
\hline
\end{tabular}


Table 2 Summary of Clinical Studies on the Use of Gabapentin for Treating Alcohol Dependence and Craving

\begin{tabular}{|c|c|c|c|c|c|c|}
\hline $\begin{array}{l}\text { Author, } \\
\text { Year }\end{array}$ & Successful? & $\begin{array}{l}\text { GBP } \\
\text { Alone, } \\
\text { Combined, } \\
\text { Contrasted? }\end{array}$ & Doses & $\begin{array}{l}\text { Initial } \\
\text { Sample } \\
\text { Size }\end{array}$ & $\begin{array}{l}\text { Sample } \\
\text { Retired } \\
\text { /Side } \\
\text { Effects }\end{array}$ & $\begin{array}{l}\text { Initial } \\
\text { Severity }\end{array}$ \\
\hline $\begin{array}{l}\text { Furieri, } \\
2007^{54}\end{array}$ & Yes, gabapentin reduces dependence and craving & Alone & $\begin{array}{l}\text { Gabapentin: } \\
300-600 \mathrm{mg} / \mathrm{d} \text {; } 28 \mathrm{~d} \\
\text { placebo } \\
\text { (both groups received } \\
\text { during baseline } \\
\text { detoxification: } \\
0-30 \mathrm{mg} / \mathrm{d} \text { diazepam, } \\
\text { vitamins, } \\
\text { emotional-physical } \\
\text { support) }\end{array}$ & $\begin{array}{l}30 \\
30\end{array}$ & $\begin{array}{l}3(r) \\
9(r)\end{array}$ & $\begin{array}{l}\text { Alcohol } \\
\text { dependence } \\
\text { (DSM-IV- } \\
\text { TR) } \\
\leq 15 \\
\text { CIWA-Ar }\end{array}$ \\
\hline $\begin{array}{l}\text { Myrick } \\
\text { et al, } \\
2007^{55}\end{array}$ & $\begin{array}{l}\text { No, gabapentin without effect on drinking or } \\
\text { craving }\end{array}$ & Alone & $\begin{array}{l}\text { Gabapentin: } \\
\text { 300-1200 mg/d; } 8 \mathrm{~d} \\
\text { Placebo }\end{array}$ & $\begin{array}{l}18 \\
17\end{array}$ & ns & $\begin{array}{l}\text { Alcohol } \\
\text { dependence } \\
\text { (DSM-IV- } \\
\text { TR) } \\
\geq 20 \text { drinks } \\
\text { in } 7 \mathrm{~d}\end{array}$ \\
\hline $\begin{array}{l}\text { Brower } \\
\text { et al, } \\
2008^{56}\end{array}$ & Yes, gabapentin delayed heavy drink & Alone & $\begin{array}{l}\text { Gabapentin: } \\
300-1500 \mathrm{mg} / \mathrm{d} ; 42 \mathrm{~d} \\
\text { Placebo } \\
\text { (both groups received } \\
\text { sessions of behavioral } \\
\text { therapy) }\end{array}$ & $\begin{array}{l}10 \\
11\end{array}$ & I (r) & $\begin{array}{l}\text { Alcohol } \\
\text { dependence } \\
\text { (DSM-IV) } \\
<8 \text { CIWA- } \\
\mathrm{Ar}\end{array}$ \\
\hline $\begin{array}{l}\text { Anton } \\
\text { et al, } \\
2009^{57}\end{array}$ & $\begin{array}{l}\text { Yes, combination of gabapentin and flumazenil, } \\
\text { effective only in group with pretreatment high } \\
\text { withdrawal }\end{array}$ & Combined & $\begin{array}{l}\text { Gabapentin + } \\
\text { flumazenil } \\
\text { gabapentin: } \\
0-1200 \mathrm{mg} / \mathrm{d} \text {; } \\
39 \mathrm{~d} \\
\text { flumazenil: } \\
2 \mathrm{mg} / \mathrm{d} \text {; } 2 \mathrm{~d} \\
\text { placebo } \\
\text { (both groups received } \\
\text { vitamins, behavioral } \\
\text { counseling) }\end{array}$ & $\begin{array}{l}\text { Low } \\
\text { withdrawal } \\
26 \\
18 \\
\text { high } \\
\text { withdrawal } \\
\text { gabapentin } \\
+ \\
\text { flumazenil: } \\
7 \\
\text { placebo: } 9\end{array}$ & ns & $\begin{array}{l}\text { Low } \\
\text { withdrawal } \\
<7 \text { CIWA- } \\
\mathrm{Ar} \\
\text { high } \\
\text { withdrawal } \\
\geq 7 \text { CIWA- } \\
\mathrm{Ar}\end{array}$ \\
\hline $\begin{array}{l}\text { Mason } \\
\text { et al, } \\
2014^{58}\end{array}$ & Yes, high dose of gabapentin & Alone & $\begin{array}{l}\text { Gabapentin: } \\
\text { 0-900 mg/d; } 84 \text { d } \\
\text { gabapentin: } \\
\text { 0-1800 mg/d; } 84 \text { d } \\
\text { placebo }\end{array}$ & $\begin{array}{l}54 \\
47 \\
49\end{array}$ & $\begin{array}{l}27(r) \\
19(r) \\
19(r)\end{array}$ & $\begin{array}{l}\text { Alcohol } \\
\text { dependence } \\
\text { (DSM-IV- } \\
\text { TR) }\end{array}$ \\
\hline
\end{tabular}

Abbreviations: CIWA-Ar, Clinical Institute Withdrawal Assessment of Alcohol Scale, Revised; DSM-IV, Diagnostic and Statistical Manual of Mental Disorders; DSM-IV-TR, Diagnostic and Statistical Manual of Mental Disorders-fourth edition- text revision; mg, milligram; ns, non specified; r, retired.

prescribed. The length of treatment was 2 days for flumazenil, and 39 days for gabapentin.

Table 2 outlines clinical studies assessing the use of gabapentin in treating alcohol dependence and craving.

\section{Clinical Studies on the Use of Gabapentin in Preventing Alcohol Relapse}

Only one study assessed the effects of gabapentin in preventing relapse. This study $(n=33)$ found that gabapentin 
Table 3 Summary of Clinical Study on the Use of Gabapentin for Treating Alcohol Relapse

\begin{tabular}{|l|l|l|l|l|l|l|}
\hline Author, Year & Successful? & $\begin{array}{l}\text { GBP } \\
\text { Alone, } \\
\text { Combined, } \\
\text { Contrasted? }\end{array}$ & Doses & $\begin{array}{l}\text { Initial } \\
\text { Sample } \\
\text { Size }\end{array}$ & $\begin{array}{l}\text { Sample } \\
\text { Retired } \\
\text { /Side Effects }\end{array}$ & $\begin{array}{l}\text { Initial } \\
\text { Severity }\end{array}$ \\
\hline Mason et al, $2009^{59}$ & Yes, may reduce relapse & Alone & $\begin{array}{l}\text { Gabapentin: } \\
300-1200 \mathrm{mg} / \mathrm{d} ; \\
7 \mathrm{~d} \\
\text { placebo }\end{array}$ & 33 & $\mathrm{~ns}$ & $\begin{array}{l}\text { Alcohol } \\
\text { dependence } \\
\text { (DSM-IV-TR) } \\
<8 \mathrm{CIWA}-\mathrm{Ar}\end{array}$ \\
\hline
\end{tabular}

Abbreviations: CIWA-Ar, Clinical Institute Withdrawal Assessment of Alcohol Scale Revised; DSM-IV-TR, Diagnostic and Statistical Manual of Mental Disorders-fourth edition-text revision; $\mathrm{mg}$, milligram; $\mathrm{ns}$, non specified.

alone, 300-1200 mg/d for 7 days, can prevent alcohol relapse. ${ }^{59}$ Additional studies are necessary to explore the efficacy of gabapentin for preventing alcohol relapse. Table 3 summarizes this study assessing the use of gabapentin for treating alcohol relapse.

\section{Clinical Studies on the Use of Gabapentin in Treating Subjective and Physiological Effects of Alcohol}

A single study found that gabapentin alone was not able to control the subjective and physiological effects of alcohol when provided at a dosage of 1000-2000 mg/d for 3 days. $^{60}$ This study had an initial sample of 22 subjects, but five did not complete the study (three withdrew for personal reasons, one due to scheduling problems, and one due to high blood pressure). More studies are necessary for exploring the suitability of gabapentin for controlling the subjective and physiological effects of alcohol. Table 4 outlines the only clinical study about the use of gabapentin for treating subjective and physiological effects of alcohol.

\section{Animal Studies About the Use of Gabapentin in Treating Alcohol-Withdrawal Symptoms}

Across two publications, one of which completed two separate experiments, gabapentin reduced convulsions, anxiety, cravings, and ethanol intake during withdrawal. ${ }^{61,68}$ These three investigations utilized a range of sample sizes: $\mathrm{n}$ initial $=18$ to $90, \mathrm{n}$ final $=13$ to 90 .

A study by Watson and colleagues (1997) of male albino mice reported that gabapentin alone reduced convulsions and anxiety related to ethanol withdrawal at doses of $50-100 \mathrm{mg} / \mathrm{kg}$ via the intraperitoneal route (ip). ${ }^{68}$ More information is displayed in Table 5.

An investigation performed in male Wistar rats found that gabapentin alone was able to dose-dependently

Table 4 Summary of Clinical Study on the Use of Gabapentin for Treating Subjective and Physiological Effects of Alcohol

\begin{tabular}{|c|c|c|c|c|c|c|}
\hline $\begin{array}{l}\text { Author, } \\
\text { Year }\end{array}$ & Successful? & $\begin{array}{l}\text { GBP } \\
\text { Alone, } \\
\text { Combined, } \\
\text { Contrasted? }\end{array}$ & Doses & $\begin{array}{l}\text { Initial } \\
\text { Sample } \\
\text { Size }\end{array}$ & $\begin{array}{l}\text { Sample } \\
\text { Retired } \\
\text { /Side } \\
\text { Effects }\end{array}$ & $\begin{array}{l}\text { Initial } \\
\text { Severity }\end{array}$ \\
\hline $\begin{array}{l}\text { Bisaga } \\
\text { and } \\
\text { Evans, } \\
2006^{60}\end{array}$ & $\begin{array}{l}\text { No, gabapentin did not altered } \\
\text { alcohol effects (subjective, } \\
\text { physiological and others) }\end{array}$ & Alone & $\begin{array}{l}\text { Gabapentin: } \\
0,1000,2000 \mathrm{mg} / \mathrm{d} \text {; } \\
3 \mathrm{~d} \text { per phase. } \\
\text { Also, } 7 \mathrm{~d} \text { washout period, and } 4 \mathrm{~h} \text { after } \\
\text { every treatment, the participants received } \\
\text { acute alcohol }(0.75 \mathrm{~g} / \mathrm{kg})\end{array}$ & 22 & $5(r)$ & $\begin{array}{l}\text { Without } \\
\text { alcohol } \\
\text { dependence } \\
\text { heavy } \\
\text { drinkers } \\
20-60 \\
\text { drinks per } \\
\text { d, } \\
7 \text { d } \\
X: 34 \text { drinks } \\
\text { in } 7 \text { d }\end{array}$ \\
\hline
\end{tabular}

Abbreviations: g/kg, grams per kilogram; h, hour; mg, milligram; ns, non specified; r, retired. 
Table 5 Summary of Animal Study on the Use of Gabapentin for Treating Alcohol-Withdrawal Symptoms

\begin{tabular}{|c|c|c|c|c|c|c|}
\hline $\begin{array}{l}\text { Author, } \\
\text { Year }\end{array}$ & Successful? & $\begin{array}{l}\text { Gabapentin } \\
\text { Alone, } \\
\text { Combined, } \\
\text { Contrasted? }\end{array}$ & Doses & $\begin{array}{l}\text { Initial Sample } \\
\text { Size }\end{array}$ & $\begin{array}{l}\text { Sample } \\
\text { Retired } \\
\text { /Side } \\
\text { Effects }\end{array}$ & $\begin{array}{l}\text { Initial } \\
\text { Severity }\end{array}$ \\
\hline $\begin{array}{l}\text { Watson } \\
\text { et al, } \\
1997^{68}\end{array}$ & $\begin{array}{l}\text { Yes, gabapentin reduced convulsions and } \\
\text { anxiety of ethanol withdrawal syndrome. } \\
\text { Also, gabapentin reduced } \\
\text { handling hyperexcitability. } \\
\text { gabapentin did not impaired } \\
\text { coordination, neither } \\
\text { basal activity }\end{array}$ & Alone & $\begin{array}{l}\text { Gabapentin } \\
\text { doses (ip): } \\
5,20,50, \\
\text { and } 100 \mathrm{mg} / \\
\mathrm{kg} \\
\text { control } \\
\text { ethanol }\end{array}$ & $\begin{array}{l}\text { Male albino mice } \\
\text { TO strain } \\
(25-35 \mathrm{~g}) \\
\text { handling } \\
\text { experiments } \\
(90) \\
\text { audiogenic } \\
\text { seizures } \\
\text { (90) } \\
\text { rotarod } \\
\text { (24) } \\
\text { anxiety } \\
\text { experiments } \\
\text { (55) } \\
\text { activity } \\
\text { experiments } \\
\text { (ns) }\end{array}$ & ns & $\begin{array}{l}\text { Induction of } \\
\text { physical } \\
\text { dependence: } \\
\text { control diet, } \\
2 \mathrm{~d} \\
3.5 \% \text { ethanol, } \\
2 \mathrm{~d} \\
7 \% \text { ethanol, } \\
5 \mathrm{~d}\end{array}$ \\
\hline $\begin{array}{l}\text { Roberto } \\
\text { et al, } \\
2008^{61} \text {; } \\
\text { behavioral } \\
\text { experiment } \\
\text { \#I }\end{array}$ & $\begin{array}{l}\text { Yes, gabapentin dose dependently } \\
\text { suppressed increases in operant ethanol } \\
\text { responding (after withdrawal from ethanol } \\
\text { vapor) }\end{array}$ & Alone & $\begin{array}{l}\text { Gabapentin } \\
\text { doses (ip): } \\
0,5,10,30, \\
\text { and } 120 \mathrm{mg} / \\
\mathrm{kg} \\
\text { (within } \\
\text { subjects- } \\
\text { latin } \\
\text { square } \\
\text { design), } \\
\text { at least } 28 \mathrm{~d}\end{array}$ & $\begin{array}{l}\text { Exposed to } \\
\text { ethanol vapor } \\
\text { (14) } \\
\text { exposed to } \\
\text { ambient air } \\
\text { (14) } \\
\text { male Wistar rats } \\
(250-300 \mathrm{~g})\end{array}$ & $\begin{array}{l}3(r) \\
0(r)\end{array}$ & $\begin{array}{l}\text { Rats trained to } \\
\text { self administer } \\
10 \%(\mathrm{w} / \mathrm{v}) \\
\text { ethanol in daily } \\
30 \mathrm{~min} \text { operant } \\
\text { sessions }\end{array}$ \\
\hline $\begin{array}{l}\text { Roberto } \\
\text { et al, } \\
2008^{61} \text {; } \\
\text { behavioral } \\
\text { experiment } \\
\# 2\end{array}$ & $\begin{array}{l}\text { Yes, Gabapentin infusion in the central } \\
\text { amygdala blocked increases in ethanol intake } \\
\text { (after withdrawal from ethanol liquid) }\end{array}$ & Alone & $\begin{array}{l}\text { Gabapentin } \\
\text { ( } 20 \text { ug) } \\
\text { or vehicle } \\
\text { infused } \\
\text { bilaterally in } \\
\text { central } \\
\text { amygdala } \\
\text { (within } \\
\text { subjects- } \\
\text { latin } \\
\text { square } \\
\text { design), } \\
98 \mathrm{~d}\end{array}$ & $\begin{array}{l}\text { Exposed to } \\
\text { ethanol } \\
\text { containing liquid } \\
\text { diet } \\
\text { (9) } \\
\text { exposed to } \\
\text { calorically } \\
\text { matched control } \\
\text { liquid diet (9) } \\
\text { male Wistar rats } \\
(250-300 \text { g) }\end{array}$ & $\begin{array}{l}3(r) \\
2(r)\end{array}$ & $\begin{array}{l}\text { Rats trained to } \\
\text { self-administer } \\
10 \%(\mathrm{w} / \mathrm{v}) \\
\text { ethanol in daily } \\
30 \mathrm{~min} \text { operant } \\
\text { sessions }\end{array}$ \\
\hline
\end{tabular}

Abbreviations: g, gram; ip, intra-peritoneal; min, minutes; $\mathrm{mg} / \mathrm{kg}$, milligram per kilogram; $\mathrm{ns}$, non specified; $\mathrm{r}$, retired; ug, microgram; \% w/v, percent of weight of solution in the total volume of solution.

suppresses the increase in operant ethanol responding after ethanol withdrawal. ${ }^{61}$ This was proven in two experiments with different routes of administration: ip (experiment \#1), and infusion in the central amygdala (experiment \#2). In the first experiment, gabapentin doses of $30-120 \mathrm{mg} / \mathrm{kg}$ (ip) suppressed the increases in operant ethanol responding 
after alcohol withdrawal (doses were $0,5,10,30$ and $120 \mathrm{mg} / \mathrm{kg}$, ip). This experiment employed an initial sample of 28 rats, but three were excluded. In the second experiment, bilateral infusion of gabapentin (20 ug) blocked increases in ethanol intake after alcohol withdrawal. The second experiment employed an initial sample of 18 rats, but five were excluded. Despite these favorable results, it seems necessary that more basic investigations on use of gabapentin for treating alcohol dependence and withdrawal symptoms be conducted.

Table 5 contains a summary of the three pre-clinical experiments on the use of gabapentin for treating alcohol dependence and/or withdrawal symptoms.

\section{Clinical Studies on the Use of Gabapentin for Reducing Tobacco Dependence}

If taking into account all the studies regardless of sample size ( $\mathrm{n}$ enrolled $=1-80 ; \mathrm{n}$ final $=1-38$ ), four studies of gabapentin for tobacco dependence were conducted between 2001 and 2010 and a successful result was found in two studies (50\%). However, if only considering trials with larger sample sizes ( $\mathrm{n}$ enrolled $=36-80, \mathrm{n}$ final $=28-38$ ), a successful result was found in only one out of the three studies $(33.3 \%)$.

Gabapentin was used alone (without any other drug) in three studies and compared to another treatment in one study. Two out of the three studies that used gabapentin alone for treating tobacco dependence showed successful results $(66.7 \%)$. One showed that gabapentin was adequate for fostering smoking abstinence, ${ }^{64}$ and the other show it was adequate for reducing misuse, craving and withdrawal symptoms of nicotine nasal spray. ${ }^{66}$ The two successful studies employed a range of 300-2400 mg/d of gabapentin. In one of the studies, the participants received a brief (10 min) behavioral intervention at each visit. ${ }^{64}$ The duration of the treatments ranged from 3 to 70 days. One participant experienced side effects and was withdrawn from the study. ${ }^{62}$

If considering only the studies with larger sample sizes ( $\mathrm{n}$ enrolled $=36$ to $80 ; \mathrm{n}$ final $=28$ to 38 ), gabapentin was utilized alone (no combined) in two investigations, and compared to another drug in one investigation. One out of the two studies that used gabapentin alone for treating tobacco dependence showed successful results $(50 \%)$. The study with favorable results reported that gabapentin (600-1800 mg/d for 56 days) was adequate for augmenting smoking abstinence. ${ }^{64}$ Gabapentin was combined with a brief behavioral intervention (10 $\mathrm{min})$ at each visit in the study. ${ }^{64}$

Among the two studies that showed negative results (n enrolled $=36-80 ; \mathrm{n}$ final $=28-38$ ), the first employed gabapentin alone, and found that gabapentin was inadequate for reducing smoking dependence after 84 days of treatment. ${ }^{61}$ Specifically, this study employed three different experimental groups: $600-1800 \mathrm{mg} / \mathrm{d}$ gabapentin, 600-2700 mg/d gabapentin, and placebo. The initial sample size was 80 participants $(27,26$ and 27 , respectively, per group), but 44 withdrew (14, 15 and 15, respectively, per group). Participants received a brief behavioral intervention for each visit (10 min). Finally, the second study with negative results contrasted the usefulness of gabapentin against bupropion for smoking (tobacco) cessation. ${ }^{65}$ This investigation used a gabapentin dose of $300-1800 \mathrm{mg} / \mathrm{d}$, and a bupropion dose of $150-300 \mathrm{mg} / \mathrm{d}$, over 6 weeks. Moreover, the participants received individual-based counseling for smoking cessation (weekly, 10 min). The initial sample was 17 subjects for the gabapentin group, and 19 subjects for the bupropion group. However, four subjects withdrew and two showed side effects in the gabapentin group; four subjects withdrew and five subjects showed side effects in the bupropion group.

Interestingly, two studies with near-identical study design and characteristics had opposing results. ${ }^{63,64}$ Both studies used gabapentin alone, employed similar doses $(600-1800 \mathrm{mg} / \mathrm{d})$, treated participants for a minimum of 8 weeks ( $56 \mathrm{~d}$ for the positive and $84 \mathrm{~d}$ for the negative), and included brief and similar behavioral interventions. The only differing variables that may explain the differing results were the sample sizes and baseline severity of tobacco dependence: ${ }^{63,64}$ the investigation with a positive result had a final sample size of 38 for its experimental group, but the study with negative result had final sample sizes of 13, 11 and 12 for each experimental group. The larger size of the positive study might be more adequately powered to find an effect for gabapentin. Regarding the severity of the participants, the study with negative results included participants with apparently more severe tobacco problems (tobacco dependence), compared to the other study with positive results $(>10$ cigarettes/d, for at least the past year).

Table 6 summarizes the clinical studies on the use of gabapentin for reducing tobacco dependence. No animal studies on the use of gabapentin for alleviating tobacco use problems were found. 
Table 6 Summary of Clinical Study About the Use of Gabapentin for Reducing Tobacco Dependence

\begin{tabular}{|c|c|c|c|c|c|c|}
\hline $\begin{array}{l}\text { Author, } \\
\text { Year }\end{array}$ & Successful? & $\begin{array}{l}\text { Gabapentin } \\
\text { Alone, } \\
\text { Combined, } \\
\text { Contrasted? }\end{array}$ & Doses & $\begin{array}{l}\text { Initial } \\
\text { Sample } \\
\text { Size }\end{array}$ & $\begin{array}{l}\text { Sample } \\
\text { Retired } \\
\text { /Side } \\
\text { Effects }\end{array}$ & $\begin{array}{l}\text { Initial } \\
\text { Severity }\end{array}$ \\
\hline $\begin{array}{l}\text { Myricke } \\
\text { al, 200166 }\end{array}$ & $\begin{array}{l}\text { Yes, gabapentin was efficacious } \\
\text { for reducing nicotine nasal spray }\end{array}$ & Alone & $\begin{array}{l}\text { Gabapentin } \\
300-900 \mathrm{mg} / \mathrm{d} \text {; } \\
3 \mathrm{~d} \\
2400 \mathrm{mg} / \mathrm{d} \text {; } \\
\text { week \#10 }\end{array}$ & 1 & 0 & $\begin{array}{l}\text { Nicotine nasal spray } \\
\text { misuse, } \\
\text { hourly consume, } \\
\text { intense craving, } \\
\text { withdrawal symptoms }\end{array}$ \\
\hline $\begin{array}{l}\text { White } \\
\text { et al, } \\
2005^{65}\end{array}$ & $\begin{array}{l}\text { No, gabapentin was less } \\
\text { efficacious than bupropion for } \\
\text { smoking cessation }\end{array}$ & Contrasted & $\begin{array}{l}\text { Gabapentin } \\
300-1800 \mathrm{mg} / \mathrm{d} \text {; } \\
42 \mathrm{~d} \\
\text { bupropion } \\
150-300 \mathrm{mg} / \mathrm{d} \text {; } \\
42 \mathrm{~d} \\
\text { individual smoking } \\
\text { cessation counseling } \\
\text { (weekly, } 10 \mathrm{~min} \text { ) }\end{array}$ & $\begin{array}{l}17 \\
19\end{array}$ & $\begin{array}{l}4(\mathrm{r}) \\
2(\mathrm{se}) \\
4(\mathrm{r}) \\
5(\mathrm{se})\end{array}$ & $\begin{array}{l}\geq 15 \text { cigarettes smoked } \\
\text { per } d \\
\geq 6 \text { score on the } \\
\text { Fagerström Test for } \\
\text { nicotine dependence }\end{array}$ \\
\hline $\begin{array}{l}\text { Sood } \\
\text { et al, } \\
2007^{64}\end{array}$ & $\begin{array}{l}\text { Yes, gabapentin may increase } \\
\text { smoking abstinence }\end{array}$ & Alone & $\begin{array}{l}\text { Gabapentin } \\
600-1800 \mathrm{mg} / \mathrm{d} \text {; } \\
56 \mathrm{~d} \\
\text { brief behavioral } \\
\text { intervention (10 min per } \\
\text { visit) }\end{array}$ & 50 & $\begin{array}{l}12(r) \\
I(s e)\end{array}$ & $\begin{array}{l}\geq 10 \text { cigarettes } / d, \text { for at } \\
\text { least the past year }\end{array}$ \\
\hline $\begin{array}{l}\text { Sood } \\
\text { et al, } \\
2010^{64}\end{array}$ & $\begin{array}{l}\text { No, gabapentin did not decreased } \\
\text { dependence }\end{array}$ & Alone & $\begin{array}{l}\text { Gabapentin } \\
600-1800 \mathrm{mg} / \mathrm{d} \text {; } \\
84 \mathrm{~d} \\
\text { gabapentin } \\
600-2700 \mathrm{mg} / \mathrm{d} \text {; } \\
84 \mathrm{~d} \\
\text { placebo } \\
84 \mathrm{~d} \\
\text { brief behavioral } \\
\text { intervention (10 min per } \\
\text { visit) }\end{array}$ & $\begin{array}{l}27 \\
26 \\
27\end{array}$ & $\begin{array}{l}14(r) \\
15(r) \\
15(r)\end{array}$ & tobacco dependence \\
\hline
\end{tabular}

Abbreviations: $\mathrm{mg}$, milligram; min, minute; $r$, retired; se, side effects.

\section{Discussion}

\section{Clinical Studies on the Use of Gabapentin for Treating Alcohol-Related Problems}

Gabapentin has been successful in treating withdrawal alcohol syndrome; while three studies had low samples $\left(n=3,{ }^{43}\right.$ $\left.4,{ }^{42,} 6,{ }^{43}\right)$, after calculating the percentages with and without these three studies, gabapentin was successful 91.7\% (11/12) of studies, and $88.9 \%(8 / 9)$ were successful if only studies with larger samples were included. Moreover, gabapentin was successful in treating alcohol dependence and cravings in $80 \%$ (4/5) of the studies reported between 2007 and 2014; as reference, none of these five studies had a small sample size ( $\mathrm{n}$ initial $=21$ to $150, \mathrm{n}$ final $=20$ to 85 ). Only one study evaluated gabapentin for treating alcohol relapse, and the authors found a positive result. ${ }^{59}$ Similarly, only one study described the use of gabapentin for controlling the subjective and physiological effects of alcohol, and it reported a negative result. ${ }^{60}$ Taking these results together, it seems that gabapentin is recommended for treating alcoholwithdrawal syndrome, alcohol dependence and craving. 
However, it is necessary to perform further research for exploring the suitability of gabapentin for alleviating alcohol relapse, and the subjective and physiological effects of alcohol.

\section{Animal Investigations About the Use of Gabapentin for Alleviating Alcohol-Related Problems}

Regarding animal research, three experimental works have explored gabapentin for alleviating alcohol-withdrawal symptoms: two experiments by Roberto and colleagues (2008) and one by Watson and colleagues (1997); ${ }^{61,68}$ for reference, these works did not use smaller sample sizes (n initial $=18-90$, $\mathrm{n}$ final $=13$ to 90 ). All found a favorable result. Based on animal research, it seems that gabapentin is adequate for reducing alcohol-withdrawal symptoms; however, it is advisable to perform more investigations due to the small number of reports on this topic. Further, it is necessary to perform further animal research on gabapentin's effects on other alcohol-related problems (ie, dependence, craving, and relapse).

\section{Clinical Studies on the Use of Gabapentin for Reducing Tobacco Dependence}

Regardless of the sample size ranges considered (all sizes or only larger sizes), there is no support for the use of gabapentin for treating tobacco dependence. If considering all sample sizes, based on the analysis of the four clinical investigations (Table 6) gabapentin use is not supported for the treatment of tobacco dependence: success was found in only $50 \%$ of the studies $(33.3 \%$ of success if only larger samples are included, $\mathrm{n}=36$ to 80$)$. Furthermore, the majority of studies (75\%) used gabapentin alone (66.7\% for larger samples studies); further studies should explore alternative combinations of gabapentin with other drugs for tobacco dependence: such as naltrexone, ${ }^{48}$ clomethiazole, ${ }^{42}$ bupropion (norepinephrine-dopamine reuptake inhibitor antidepressant), ${ }^{65}$ or cytisine and varenicline (partial agonists of nicotinic acetylcholine receptors). As a reference, the investigations that combined gabapentin with clomethiazole or naltrexone for treating alcohol abuse problems (described here) used gabapentin doses of $1600 \mathrm{mg} /$ $\mathrm{d}^{42}$ and 300-1200 mg/d, ${ }^{48}$ respectively; these dosages can be of reference for combinations targeting tobacco use problems.

However, gabapentin was found to foster smoking abstinence, ${ }^{64}$ and reduce misuse, craving and withdrawal symptoms of nicotine nasal spray. ${ }^{66}$ The range of dosage in the successful studies was 300 to $2400 \mathrm{mg} / \mathrm{d}$, which is similar to the range found in the studies described previously for treatment of alcohol disorders (withdrawal symptoms: 400-3200 mg/d).

Some limitations in this review of gabapentin for tobacco-related problems were the limited number of studies in the field (four), a small sample size $(n=1)$ of one included study, ${ }^{66}$ and the absence of animal studies on this topic (which could complement the analysis of clinical studies). It is therefore recommended that more double-blind, randomized, and large sample clinical trials for exploring gabapentin's usefulness for treating tobacco-related problems (dependence, craving, withdrawal symptoms) be conducted. Moreover, clinical and rodent studies that explore different routes of gabapentin administration (oral, systemic, nasal) for treating tobaccorelated problems (dependence, craving, withdrawal symptoms) would be beneficial. Finally, future studies (human and rodent) should analyze different forms of tobacco use besides smoking, such as chewing and inhaled (snuffed).

\section{Conclusions}

\section{Conclusions Integrating Clinical and} Animal Investigations Regarding the Use of Gabapentin for Treating Alcohol-Related Problems

Taken together, clinical and animal investigations support the use of gabapentin for alleviating alcohol-withdrawal symptoms. If considering all studies, regardless of samples size, among 15 investigations (12 clinical and three animal), 14 $(93.3 \%)$ found gabapentin to be successful for the alleviation of alcohol-withdrawal symptoms. Moreover, if studies with smaller samples sizes are excluded, gabapentin use is still supported (91.7\% success, 11/12).

\section{Conclusions About the Use of Gabapentin for Alleviating Tobacco-Related Problems}

If considering all the investigations, regardless of sample sizes, a total of four studies have explored the use of gabapentin for treating tobacco dependence, with a result in $50 \%$ of the reports; similar results are found if only larger sample studies are considered (success in 1/3 studies). This does not support the use of gabapentin for alleviating tobacco-related problems. A limitation was the scarce number of clinical studies (four) and the absence of related rodent studies in this field. Hence, it is recommended that researchers perform more studies with large samples. Also, subsequent studies should consider other 
routes of gabapentin administration, and different forms of tobacco consumption. These subsequent studies would help to define the suitability of gabapentin for alleviating tobacco dependence problems.

\section{Acknowledgments}

We would like to thank Open Access Publishing Fund from Florida State University Libraries for it's funding. Thanks to Dr. Anthony L Vaccarino (INDOC Research, Toronto), and MS Sophia Vaccarino (St. Michael's Hospital, Toronto) for their useful comments and revisions to this manuscript. Dr. G. Quintero Garzola was partially backed until 2019 by the SNI (Sistema Nacional de Investigacion) from SENACYT. SENACYT is a public organization located in Panama.

\section{Disclosure}

The author reports no conflicts of interest for this work.

\section{References}

1. Zullino DF, Khazaal Y, Hattenschwiler J, Borgeat F, Besson J. Anticonvulsant drugs in the treatment of substance withdrawal. Drugs Today. 2004;40:603-619. doi:10.1358/dot.2004.40.7.850478

2. Howland RH. Gabapentin for substance use disorders: is it safe and appropriate? J Psychosoc Nurs Ment Health Serv. 2004;52:13-16.

3. National Center for Biotechnology Information. Pub chem substance database. Bethesda, U.S.A: U.S. National Library of Medicine; December 1, 2016. Available from: https://pubchem.ncbi.nlm.nih. gov/substance/46506529D. Accessed August 27, 2020.

4. Drug Information Portal. Search Drug Information Portal. Bethesda, U.S.A: U.S. National Library of Medicine. Recovered from: https:// druginfo.nlm.nih.gov/drugportal/name/Gabapentin. Accessed August 27, 2020. (April 1, 2016).

5. Bockbrader HN, Wesche D, Miller R, Chapel S, Janiczek N, Burger P. A comparison of the pharmacokinetics and pharmacodynamics of pregabalin and gabapentin. Clin Pharmacokinet. 2010;49 (10):661-669. doi:10.2165/11536200-000000000-00000

6. Dickenson AH, Ghandehari J. Anti-convulsants and anti-depressants. Handb Exp. 2007;145-177.

7. Landmark CJ. Targets for antiepileptic drugs in the synapse. Med Sci Monit. 2007;13:RA1-7.

8. Rogawski MA, Loscher W. The neurobiology of antiepileptic drugs. Nat Rev Neurosci. 2004;5:553-564. doi:10.1038/nrn1430

9. Coderre TJ, Kumar N, Lefebvre CD, Yu JS. A comparison of the glutamate release inhibition and anti-allodynic effects of gabapentin, lamotrigine, and riluzole in a model of neuropathic pain. J Neurochem. 2007;100:1289-1299. doi:10.1111/j.1471-4159.2006.04304.x

10. Cunningham MO, Woodhall GL, Thompson SE, Dooley DJ, Jones RS. Dual effects of gabapentin and pregabalin on glutamate release at rat entorhinal synapses in vitro. Eur $J$ Neurosci. 2004;20:1566-1576. doi:10.1111/j.1460-9568.2004.03625.x

11. Eroglu CAN, Susman MW, O'Rourke NA, et al. Gabapentin receptor a2d-1 is a neuronal thrombospondin receptor responsible for excitatory CNS synaptogenesis. Cell. 2009;139:380-392. doi:10.1016/j. cell.2009.09.025

12. Bauer CST-V-MA, Kadurin I, Dolphin AC. A new look at calcium channel $\alpha 2 \delta$ subunits. Curr Opin Neurobiol. 2010;20:1-9. doi:10.1016/j.conb.2010.05.007
13. Gabapentin and pregabalin: abuse and addiction. Prescrire Int. 2012;21(128):152-154.

14. Hengy H, Kolle EU. Determination of gabapentin in plasma and urine by high-performance liquid chromatography and pre-column labelling for ultraviolet detection. $J$ Chromatogr. 1985;341 (2):473-478. doi:10.1016/S0378-4347(00)84064-5

15. Vollmer KO, von Hodenberg A, Kolle EU. Pharmacokinetics and metabolism of gabapentin in rat, dog and man. Arzneimittelforschung. 1986;36(5):830-839.

16. Reimann W. Inhibition by GABA, baclofen and gabapentin of dopamine release from rabbit caudate nucleus: are there common or different sites of action?. Eur J Pharmacol. 1983;94(34):341-344.

17. Schlicker E, Reimann W, Gothert M. Gabapentin decreases monoamine release without affecting acetylcholine release in the brain. Arzneimittelforschung. 1985;35(9):1347-1349.

18. Bartoszyk GD, Hamer M. The genetic animal model of reflex epilepsy in the Mongolian gerbil: differential efficacy of new anticonvulsive drugs and prototype antiepileptics. Pharmacol Res Commun. 1987;19(6):429-440. doi:10.1016/0031-6989(87)90082-8

19. Crawford P, Ghadiali E, Lane R, Blumhardt L, Chadwick D. Gabapentin as an antiepileptic drug in man. $J$ Neurol Neurosurg Psychiatry. 1987;50(6):682-686. doi:10.1136/jnnp.50.6.682

20. Ryback R, Ryback L. Gabapentin for behavioral dyscontrol. Am J Psychiatry. 1995;152(9):1399.

21. Walden J, Hesslinger B. Value of old and new anticonvulsants in treatment of psychiatric diseases. Fortschr Neurol Psychiatr. 1995;63 (8):320-335. doi:10.1055/s-2007-996633

22. Welty DF, Schielke GP, Rothstein JD. Potential treatment of amyotrophic lateral sclerosis with gabapentin: a hypothesis. Ann Pharmacother. 1995;29(11):1164-1167. doi:10.1177/106002809502901118

23. Shimoyama M, Shimoyama N, Inturrisi CE, Elliott KJ. Gabapentin enhances the antinociceptive effects of spinal morphine in the rat tail-flick test. Pain. 1997;72(3):375-382. doi:10.1016/S0304-3959(97)00065-1

24. Rosner H, Rubin L, Kestenbaum A. Gabapentin adjunctive therapy in neuropathic pain states. Clin J Pain. 1996;12(1):56-58. doi:10.1097/ 00002508-199603000-00010

25. Ryback RS, Brodsky L, Munasifi F. Gabapentin in bipolar disorder. J Neuropsychiatry Clin Neurosci Spring. 1997;9(2):301. doi:10.1176/ jnp.9.2.301

26. Singh L, Field MJ, Ferris P, et al. The antiepileptic agent gabapentin (Neurontin) possesses anxiolytic-like and antinociceptive actions that are reversed by D-serine. Psychopharmacology. 1996;127(1):1-9. doi:10.1007/BF02805968

27. Segal AZ, Rordorf G. Gabapentin as a novel treatment for postherpetic neuralgia. Neurology. 1996;46(4):1175-1176. doi:10.1212/ WNL.46.4.1175

28. Mellick GA, Mellick LB. Management of restless legs syndrome with gabapentin (Neurontin). Sleep. 1996;19(3):224-226. doi:10.1093/sleep/ 19.3.224

29. Adler CH. Treatment of restless legs syndrome with gabapentin. Clin Neuropharmacol. 1997;20(2):148-151. doi:10.1097/00002826199704000-00006

30. Nunes EV. Gabapentin: a new addition to the armamentarium for alcohol dependence? JAMA Intern Med. 2014;174(1):78-79. doi:10.1001/jamainternmed.2013.11973

31. Leung JG, Hall-Flavin D, Nelson S, Schmidt KA, Schak KM. The role of gabapentin in the management of alcohol withdrawal and dependence. Ann Pharmacother. 2015;49:897-906. doi:10.1177/ 1060028015585849

32. Olive MF, Cleva RM, Kalivas PW, Malcolm RJ. Glutamatergic medications for the treatment of drug and behavioral addictions. Pharmacol Biochem Behav. 2012;100(4):801-810. doi:10.1016/j. pbb.2011.04.015

33. Prince V, Turpin KR. Treatment of alcohol withdrawal syndrome with carbamazepine, gabapentin, and nitrous oxide. Am J Health Syst Pharm. 2008;65(11):1039-1047. doi:10.2146/ajhp070284 
34. Muller CA, Geisel O, Banas R, Heinz A. Current pharmacological treatment approaches for alcohol dependence. Expert Opin Pharmacother. 2014;15(4):471-481. doi:10.1517/ 14656566.2014.876008

35. Muncie HL Jr, Yasinian Y, Oge L. Outpatient management of alcohol withdrawal syndrome. Am Fam Physician. 2013;88(9):589-595.

36. Lyon J. More treatments on deck for alcohol use disorder. JAMA. 2017;317(22):2267-2269. doi:10.1001/jama.2017.4760

37. Soyka M, Muller CA. Pharmacotherapy of alcoholism - an update on approved and off-label medications. Expert Opin Pharmacother. 2017;18(12):1187-1199. doi:10.1080/14656566.2017.1349098

38. Pani PP, Trogu E, Pacini M, Maremmani I. Anticonvulsants for alcohol dependence. Cochrane Database Syst Rev. 2014;2: CD008544.

39. Winslow BT, Onysko M, Hebert M. Medications for alcohol use disorder. Am Fam Physician. 2016;93(6):457-465.

40. Aubin HJ, Luquiens A, Berlin I. Pharmacotherapy for smoking cessation: pharmacological principles and clinical practice. $\mathrm{Br}$ J Clin Pharmacol. 2014;77(2):324-336. doi:10.1111/bcp.12116

41. Schnoll RA, Lerman C. Current and emerging pharmacotherapies for treating tobacco dependence. Expert Opin Emerg Drugs. 2006;11 (3):429-444. doi:10.1517/14728214.11.3.429

42. Bonnet U, Banger M, Leweke FM, Maschke M, Kowalski T, Gastpar M. Treatment of alcohol withdrawal syndrome with gabapentin. Pharmacopsychiatry. 1999;32:107-109. doi:10.1055/ s-2007-979203

43. Bozikas V, Petrikis P, Gamvrula K, Savvidou I, Karavatos A. Treatment of alcohol withdrawal with gabapentin. Prog Neuropsychopharmacol Biol Psychiatry. 2002;26:197-199. doi:10.1016/S0278-5846(01)00234-2

44. Rustembegovic A, Sofic E, Tahirovic I, Kundurovic Z. A study of gabapentin in the treatment of tonic-clonic seizures of alcohol withdrawal syndrome. Med Arh. 2004;58(1):5-6.

45. Mariani JJ, Rosenthal RN, Tross S, Singh P, Anand OP. A randomized, open-label, controlled trial of gabapentin and phenobarbital in the treatment of alcohol withdrawal. Am J Addict. 2006;15 (1):76-84. doi:10.1080/10550490500419110

46. Malcolm R, Myrick LH, Veatch LM, Boyle E, Randall PK. Selfreported sleep, sleepiness, and repeated alcohol withdrawals: a randomized, double blind, controlled comparison of lorazepam vs gabapentin. J Clin Sleep Med. 2007;3(1):24-32.

47. Myrick H, Malcolm R, Randall PK, et al. A double-blind trial of gabapentin versus lorazepam in the treatment of alcohol withdrawal. Alcohol Clin Exp Res. 2009;33:1582-1588. doi:10.1111/j.15300277.2009.00986.x

48. Anton RF, Myrick H, Wright TM, et al. Gabapentin combined with naltrexone for the treatment of alcohol dependence. Am J Psychiatry. 2011;168(7):709-717. doi:10.1176/appi.ajp.2011.10101436

49. Stock CJ, Carpenter L, Ying J, Greene T. Gabapentin versus chlordiazepoxide for outpatient alcohol detoxification treatment. Ann Pharmacother. 2013;47(78):961-969. doi:10.1345/aph.1R751

50. Stock CJ, Carpenter L, Ying J, Greene T. Reply to comment on "gabapentin versus chlordiazepoxide for outpatient alcohol detoxification treatment". Ann Pharmacother. 2013;47(12):1743. doi:10.1177/1060028013509366

51. Bonnet U, Specka M, Leweke FM, Nyhuis $P$, Banger $M$. Gabapentin's acute effect on mood profile - a controlled study on patients with alcohol withdrawal. Prog Neuropsychopharmacol Biol Psychiatry. 2007;31(2):434-438. doi:10.1016/j.pnpbp.2006.11.006

52. Bonnet U, Banger M, Leweke FM, et al. Treatment of acute alcohol withdrawal with gabapentin: results from a controlled two-center trial. J Clin Psychopharmacol. 2003;23(5):514-519. doi:10.1097/01. jcp.0000088905.24613.ad
53. Bonnet U, Hamzavi-Abedi R, Specka M, Wiltfang J, Lieb B, Scherbaum N. An open trial of gabapentin in acute alcohol withdrawal using an oral loading protocol. Alcohol Alcohol. 2010;45 (2):143-145. doi:10.1093/alcalc/agp085

54. Furieri FA, Nakamura-Palacios EM. Gabapentin reduces alcohol consumption and craving: a randomized, double-blind, placebo-controlled trial. J Clin Psychiatry. 2007;68(11):1691-1700. doi:10.4088/JCP.v68n1108

55. Myrick H, Anton R, Voronin K, Wang W, Henderson S. A double-blind evaluation of gabapentin on alcohol effects and drinking in a clinical laboratory paradigm. Alcohol Clin Exp Res. 2007;31 (2):221-227. doi:10.1111/j.1530-0277.2006.00299.x

56. Brower KJ, Myra Kim H, Strobbe S, Karam-Hage MA, Consens F, Zucker RA. A randomized double-blind pilot trial of gabapentin versus placebo to treat alcohol dependence and comorbid insomnia. Alcohol Clin Exp Res. 2008;32(8):1429-1438. doi:10.1111/j.15300277.2008.00706.x

57. Anton RF, Myrick H, Baros AM, et al. Efficacy of a combination of flumazenil and gabapentin in the treatment of alcohol dependence: relationship to alcohol withdrawal symptoms. $J$ Clin Psychopharmacol. 2009;29(4):334-342. doi:10.1097/ JCP.0b013e3181aba6a4

58. Mason BJ, Quello S, Goodell V, Shadan F, Kyle M, Begovic A. Gabapentin treatment for alcohol dependence: a randomized clinical trial. JAMA Intern Med. 2014;174(1):70-77. doi:10.1001/ jamainternmed.2013.11950

59. Mason BJ, Light JM, Williams LD, Drobes DJ. Proof-of-concept human laboratory study for protracted abstinence in alcohol dependence: effects of gabapentin. Addict Biol. 2009;14(1):73-83. doi:10.1111/j.1369-1600.2008.00133.x

60. Bisaga A, Evans SM. The acute effects of gabapentin in combination with alcohol in heavy drinkers. Drug Alcohol Depend. 2006;83 (1):25-32. doi:10.1016/j.drugalcdep.2005.10.008

61. Roberto M, Gilpin NW, O’Dell LE, et al. Cellular and behavioral interactions of gabapentin with alcohol dependence. J Neurosci. 2008;28(22):5762-5771. doi:10.1523/JNEUROSCI.0575-08.2008

62. Clemens KJ, Vendruscolo LF. Anxious to drink: gabapentin normalizes GABAergic transmission in the central amygdala and reduces symptoms of ethanol dependence. J Neurosci. 2008;28 (37):9087-9089. doi:10.1523/JNEUROSCI.2928-08.2008

63. Sood A, Ebbert JO, Wyatt KD, et al. Gabapentin for smoking cessation. Nicotine Tob Res. 2010;12(3):300-304. doi:10.1093/ntr/ ntp195

64. Sood A, Ebbert JO, Schroeder DR, et al. Gabapentin for smoking cessation: a preliminary investigation of efficacy. Nicotine Tob Res. 2007;9(2):291-298. doi:10.1080/14622200601080307

65. White WD, Crockford D, Patten S, El-Guebaly N. A randomized, open-label pilot comparison of gabapentin and bupropion SR for smoking cessation. Nicotine Tob Res. 2005;7(5):809-813. doi:10.1080/14622200500259887

66. Myrick H, Malcolm R, Henderson S, McCormick K. Gabapentin for misuse of homemade nicotine nasal spray. Am J Psychiatry. 2001;158 (3):498. doi:10.1176/appi.ajp.158.3.498

67. Myrick H, Malcolm R, Brady KT. Gabapentin treatment of alcohol withdrawal. Am J Psychiatry. 1998;155(11):1632. doi:10.1176/ ajp.155.11.1626j

68. Watson WP, Robinson E, Little HJ. The novel anticonvulsant, gabapentin, protects against both convulsant and anxiogenic aspects of the ethanol withdrawal syndrome. Neuropharmacology. 1997;36 (10):1369-1375. doi:10.1016/S0028-3908(97)00118-4 


\section{Publish your work in this journal}

The Open Access Journal of Clinical Trials is an international, peerreviewed, open access journal publishing original research, reports, editorials, reviews and commentaries on all aspects of clinical trial design, management, legal, ethical and regulatory issues, case record form design, data collection, quality assurance and data auditing methodologies. The manuscript management system is completely online and includes a very quick and fair peer-review system, which is all easy to use. Visit http://www.dovepress.com/testimonials.php to read real quotes from published authors. 